\title{
Psikoeduakasi C4ME untuk Mengatasi Gangguan Sindrom Pramenstruasi Pada Taruni Militer
}

\section{C4ME Psychoeduacation for Overcoming Premenstrual Syndrome Disorder in Military Women Cadets}

\author{
Eunike Setiawati, Andri Adi Wijaya, Sri Wahyuningsih \\ Fakultas Psikologi Universitas Surabaya, Indonesia
}

\begin{abstract}
Different situations and lifestyles in the military education academy require the women Navy cadets to adapt to high levels of stress. Stress can potentially disrupt the menstrual cycle and worsen the symptoms of premenstrual syndrome (PMS) which can reduce their performance as military cadets. This study aims to determine the effect of psychoeducation of Care For Menstruation (C4ME) on overcoming PMS problems in the Navy Academy. C4ME covers health counseling activities that provide information about menstruation and involves interventions based on cognitivebehavioral techniques to cope with PMS symptoms. This quasi-experiment used nonrandomized one-group pretest-posttest design. Fifteen women Navy cadets were recruited. Quantitative data were collected using questionnaires of knowledge and attitude towards menstruation and were analyzed using a parametric statistical tcorrelated sample. Qualitative data were collected from interviews before and after the intervention and were analyzed using a content analysis. The results show that C4ME psychoeducation is effective in increasing knowledge of menstruation $(\mathrm{p}=0.01)$, changing participants' attitudes toward menstruation being more positive $(\mathrm{p}<0.01)$ and decreasing the symptoms of PMS experienced by participants.
\end{abstract}

Keywords: C4ME Psychoeducation, premenstrual syndrome, women navy cadet

\begin{abstract}
Abstrak: Perbedaan situasi dan gaya hidup di akademi pendidikan militer menuntut para taruni Akademi Angkatan Laut (AAL) untuk beradaptasi dengan level stres yang tinggi. Stres berpotensi dapat mengganggu siklus menstruasi dan memperparah gejala sindrom pramenstruasi (PMS) yang dapat menurunkan produktifitas taruni. Penelitian ini bertujuan untuk menguji pengaruh psikoedukasi Care For Menstruation (C4ME) dalam mengatasi masalah PMS pada taruni AAL. Program psikoedukasi meliputi kegiatan penyuluhan kesehatan dan intervensi dengan teknik kognitif-perilaku untuk mengatasi gejala PMS. Metode kuasi-eksperimen dengan non-randomized design onegrup pretest-posttest digunakan. Partisipan penelitian adalah lima belas orang taruni AAL. Data kuantitatif tentang pengetahuan dan sikap terhadap menstruasi diukur menggunakan kuesioner, sedangkan data kualitatif diperoleh melalui wawancara sebelum dan sesudah dilakukan intervensi. Data kuantitatif dianalisis dengan statistik parametrik t-correlated sample, sedangkan data kualitatif dianalisis menggunakan analisis konten. Hasil menunjukkan bahwa psikoedukasi tentang menstruasi efektif dalam meningkatkan pengetahuan $(\mathrm{p}=0,01)$, mengubah sikap partisipan menjadi lebih positif terhadap menstruasi $(\mathrm{p}<=0,01)$, dan menurunkan gejala PMS pada para taruni.
\end{abstract}

Kata Kunci: Psikoedukasi C4ME sindrom pramenstruasi, taruni militer

Korespondensi tentang artikel ini dapat dialamatkan kepada Eunike Setiawati melalui E-mail: eunike.setiawati@gmail.com 
Sindrom pramenstruasi (PMS) atau premenstrual disorders merupakan kumpulan berbagai simtom fisik, emosional dan perilaku yang berkaitan dengan siklus menstruasi pada perempuan. Gejala-gejala tersebut muncul setelah ovulasi yaitu pada akhir fase luteal (hari ke 21-28 dari siklus menstruasi) dan menghilang saat hari pertama menstruasi (Siahbazi, Montazeri, Taghizadeh, \& Masoomie, 2018; Sigmon, Craner, Yoon, \& Thorpe, 2012). Gangguan pramenstruasi dipengaruhi oleh faktor fisik-biologis, psikologis dan lingkungan sosial (Sigmon et al., 2012).

Secara fisik, menstruasi merupakan proses biologis dan erat kaitannya dengan faktor genetik atau keturunan, hormonal serta kadar kimiawi (neurotransmitter) di dalam otak. Status gizi juga berpengaruh secara signifikan pada gangguan sindrom pramenstruasi (Estiani \& Nindya, 2018; Sigmon et al., 2012). Hasil penelitian Nashruna, Maryatum dan Wulandari (2012) serta Namsa, Palandeng dan Kallo (2015) juga melaporkan bahwa perempuan yang memiliki status gizi buruk berpeluang lebih besar mengalami gangguan pramenstruasi. Kecukupan mineral dalam tubuh seperti kalsium, magnesium serta vitamin B6 juga turut memengaruhi timbul atau tidaknya simtom (Ramadani, 2012).

Faktor lingkungan sosial yang memengaruhi timbulnya simtom gangguan pramenstruasi adalah keyakinan budaya yang salah tentang menstruasi. Pandangan budaya yang negatif terhadap menstruasi (misal menstruasi dianggap kotor sehingga tabu dibicarakan) akan membentuk sikap yang negatif terhadap menstruasi. Sikap terhadap menstruasi berperan penting dalam menentukan muncul atau tidaknya simtom gangguan pramenstruasi dan intensitasnya (Zendehdel \& Elyasi, 2018). Sigmon et al. (2012) juga mengemukakan bahwa sikap negatif terhadap menstruasi memengaruhi reaktifitas emosional sehingga perempuan jadi lebih sensitif merespon emosi negatif.

Faktor psikologis yang memengaruhi derajat keparahan kondisi gangguan pramenstruasi adalah kecenderungan karakter kepribadian yang perfeksionis (Chrisler, 2008). Individu yang perfeksionis memiliki tingkat kecemasan yang tinggi dan lebih rentan stres. Stres berkepanjangan mengakibatkan gangguan pada sistem neuroendokrin yang dapat memicu munculnya simtom gangguan pramenstruasi (Budarapu et al., 2018).

Sejalan dengan penjelasan dari perspektif biopsikososial, pendekatan model kognitif dari Blake (Blake, 1995; Kleinstäuber, Schmelzer, Ditzen, Hiller, Andersson, \& Weise, 2016) menjelaskan bahwa etiologi gangguan pramenstruasi berkaitan dengan appraisal kognitif dan kemampuan coping individu. Appraisal adalah pemaknaan individu terhadap peristiwa dan pengalaman dalam hidupnya. Proses appraisal individu pada perubahan fisik dan emosional saat memasuki fase luteal akan sangat memengaruhi atribusinya terhadap keseluruhan simtom gangguan pramenstruasi. Pemaknaan negatif memicu timbulnya sikap yang negatif begitu pula sebaliknya.

Faktor-faktor lain yang memengaruhi appraisal adalah persepsi dan reaktifitas emosional dalam merespon situasi lingkungan. Persepsi yang negatif terhadap lingkungan sosial yang tidak mendukung (misalnya: ejekan, hinaan; tidak adanya fasilitas toilet yang bersih) akan meningkatkan reaktifitas emosional yang terwujud dalam kecemasan menjelang menstruasi. Appraisal yang negatif terhadap menstruasi biasanya juga memicu strategi coping maladaptif. Ussher dan Perz (2010) mengemukakan bahwa avoidance coping merupakan strategi coping yang paling tidak efektif dalam mengatasi gangguan pramenstruasi.

Dari penjelasan tersebut di atas dapat disimpulkan bahwa faktor psikososial berperan penting dalam menentukan tingkat keparahan gangguan pramenstruasi khususnya appraisal kognitif. Appraisal kognitif yang terbentuk akan memengaruhi pembentukan sikap individu terhadap menstruasi. Salah satu faktor yang mendukung timbulnya sikap negatif adalah 
rendahnya pengetahuan yang adekuat tentang menstruasi (Yadav, Joshi, Poudel, \& Pandeya, 2018).

Masalah gangguan pramenstruasi juga dialami sekitar $30 \%$ dari populasi taruni Angkatan Laut (AL). Taruni adalah sebutan untuk siswi Akademi Angkatan Laut (AAL) yang berusia 19 hingga 21 tahun. Penelitian Hourani, Yuan, \& Bray (2004) mendukung fenomena tersebut, yaitu perempuan yang berkarir dalam bidang militer memiliki prevalensi tinggi mengalami premenstrual syndrome. Simtom fisiologis gangguan pramenstruasi yang sering dialami adalah kram perut, mual, konstipasi, sakit kepala, mudah lelah serta berjerawat. Sedangkan simtom emosionalnya adalah perasaan tidak percaya diri, mood swing, menurunnya konsentrasi dan mudah marah (irritable). (Rapkin \& Lewis, 2013).

Gangguan pramenstruasi yang dialami oleh para taruni AAL berdampak negatif pada beberapa aspek hidupnya. Pada aspek kesehatan reproduksi, taruni kerap mengalami gangguan siklus menstruasi. Sedangkan pada aspek psikologis, terjadi penurunan kesejahteraan psikologis individu yang dapat mengarah pada kondisi depresi.

Penurunan produktifitas juga terjadi karena para taruni sering absen dari kegiatan belajar di dalam kelas maupun latihan fisik outdoor yang merupakan bagian dari pelatihan militer (Budarapu et al., 2018; Forrester-Knauss, Zemp Stutz, Weiss, \& Tschudin, 2011). Pada aspek relasi sosial, taruni yang mengalami gangguan pramenstruasi sering dijadikan bahan candaan taruna (siswa laki-laki akademi militer) sehingga taruni merasa tidak nyaman dalam pergaulan (Reberte, de Andrade, Hoga, Rudge, \& Rodolpho, 2014).

Kondisi kehidupan taruni sebagai personil militer memang berbeda dengan remaja seusianya. Hal ini disebabkan oleh adanya perbedaan tujuan pendidikan militer dan tujuan pendidikan pada masyarakat sipil. Tujuan pendidikan militer adalah mempersiapkan taruni menyelesaikan misi di bawah tekanan dalam medan pertempuran. Karena itu, materi pelatihan dasar militer memang dirancang menjadi stresor biopsikososial yang mengakibatkan peningkatan hormon kortisol dan tekanan psikologis (Nakkas, Annen, \& Brand, 2016). Tidak mengherankan jika taruni dituntut dapat beradaptasi dengan pola pelatihan militer yang mengutamakan kekuatan fisik dan ketangguhan emosional yang tinggi seperti laki-laki. Namun demikian, taruni tetap dituntut untuk memertahankan sisi femininnya dan dapat menunjukkan sikap keibuan. Kedua tuntutan yang bertolak belakang tersebut menjadi stressor utama taruni.

Selain tuntutan performa akademis, Ilagan, Simpson, Shealy, Bennett-Mintz dan McCormick (2016) mengemukakan bahwa taruni juga seringkali mengalami tekanan sebagai kaum minoritas di lingkungannya. Diketahui bahwa rasio jumlah taruni dan taruna adalah 1:10 untuk setiap angkatan. Oleh karena itu taruni dianggap sebagai kaum minoritas. Terkait isu diskriminasi, Do, Samuels, Adkins, Clinard, \& Koveleskie (2013) mengemukakan bahwa budaya militer yang maskulin rentan memunculkan sikap diskriminatif. Komentar verbal yang negatif umum terjadi saat taruni mengekspresikan kejengkelan atau kemarahannya secara terbuka. Akibatnya taruni lebih sering menahan diri untuk mengungkapkan pikiran dan perasaannya untuk menghindari adanya konflik (coping self silencing).

Perz dan Ussher (2006) menemukan bahwa perempuan yang mengalami gangguan pramenstruasi sering mengandalkan strategi coping self silencing untuk mengatasi masalah dalam relasi. Self-silencing adalah upaya untuk berhati-hati membatasi ekspresi pikiran, perasaan serta perilaku yang dianggap berpotensi menimbulkan konflik inter-personal atau konsekuensi negatif lainnya (Chrisler, Gorman, \& Streckfuss, 2014). Strategi ini cukup efektif jika dilakukan dalam jangka waktu pendek. Namun, jika terlalu bergantung 
pada strategi coping tersebut untuk menghindari konflik relasi maka pelakunya akan berpotensi besar mengalami masalah psikologis seperti kesepian, kemarahan, penurunan self esteem, serta self-criticism yang tinggi. Strategi coping ini juga berpotensi memicu perasaan terisolasi dari lingkungan dan dapat menurunkan kesejahteraan psikologis (Perz \& Ussher, 2006).

Kondisi hidup yang penuh tekanan dan rendahnya pengetahuan tentang coping pengelolaan stres yang adaptif makin meningkatkan potensi timbulnya gangguan pramenstruasi pada taruni (Hourani et al., 2004; Nakkas et al., 2016). Read, Perz dan Ussher (2014) menambahkan bahwa memelajari strategi coping yang efektif dalam mengelola stres dapat meringankan simtom gangguan pramenstruasi. Salah satu cara yang dapat dilakukan untuk mengatasi gangguan pramenstruasi adalah melalui intervensi atau edukasi kesehatan seputar menstruasi (Lustyk, Gerrish, Shaver, \& Keys, 2009; Zendehdel \& Elyasi, 2018). Pengetahuan dan pemahaman yang adekuat tentang menstruasi dapat mengubah sikap taruni menjadi lebih positif dan sekaligus meningkatkan coping yang efektif.

Selain intervensi kesehatan atau medis, intervenesi psikologis juga diperlukan. King dan Ussher (2013) mengemukakan kelebihan intervensi psikologis dibandingkan intervensi medis yaitu dapat meminimalkan kontraindikasi pengobatan medis terhadap tubuh sehingga relatif lebih aman. Komandan taruni menyatakan bahwa belum ada penyuluhan atau edukasi yang secara rutin membekali taruni dengan pengetahuan tentang kesehatan reproduksi dalam konteks kehidupan akademi militer. Karena itu, peneliti melihat adanya kebutuhan intervensi berupa psikoedukasi.

Psikoedukasi merupakan salah satu strategi intervensi psikologis yang dapat digunakan untuk mengubah pengetahuan dan sikap sekelompok orang dalam suatu komunitas (Bashiri, Aghajani, \& Alavi, 2016; Ghafoori, Fisher, Korosteleva, \& Hong, 2016; Rahmani, Ranjbar, Ebrahimi, \& Hosseinzadeh, 2015). Psikoedukasi tentang menstruasi diyakini dapat meningkatkan pengetahuan dan kesadaran para taruni tentang potensi gejala PMS yang mereka alami. Kleinstäuber et al. (2016) menyatakan bahwa kesadaran (awareness) dan penerimaan (acceptance) terhadap simtom gangguan pramenstruasi merupakan bentuk appraisal yang positif sehingga lebih adaptif.

Penelitian sebelumnya menunjukkan bahwa intervensi dengan pendekatan teknik kognitif-perilaku efektif untuk menurunkan simtom fisik maupun psikologis terkait gangguan pramenstruasi (Askari, Behroozi, \& Abbaspoor, 2018; Karimi, Dehkordi, Alipour, \& Mohtashami, 2018; Ussher \& Perz, 2017; Lustyk, Gerrish, Douglas, Bowen, \& Marlatt, 2011). Berdasarkan penelitian tersebut, program psikoedukasi pada penelitian ini dirancang menggunakan pendekatan kognitif perilaku yang merujuk pada teknik mindfulness dan cognitive behavioral therapy. Peneliti memertimbangkan perbedaan pada kondisi hidup taruni dengan remaja lain seusianya dalam penyusunan intervensi yaitu perlu adanya pengelolaan stres fisik pada level lanjutan (advanced).

Dari paparan permasalahan di atas maka peneliti menyusun progam psikoedukasi Care for Menstruation (C4ME) bagi para taruni Akademi Angkatan Laut. Tujuan program tersebut adalah untuk memberikan informasi seputar menstruasi dan mengajarkan strategi coping untuk mengelola stres yang merupakan faktor penting dari PMS. Diharapkan sikap taruni pada menstruasi menjadi lebih positif dan dapat menerima perubahan fisik maupun psikologis yang terjadi pada saat fase pramenstruasi. Dengan meningkatnya penerimaan diri maka level keparahan simtom gangguan pramenstruasi juga dapat diminimalisir.

Hipotesis penelitian ini adalah bahwa psikoedukasi C4ME berbasis pendekatan kognitif-perilaku dapat mengubah sikap taruni AAL menjadi lebih positif pada menstruasi. 


\section{Metode}

Penelitian ini menggunakan kuasieksperimental dengan menggunakan nonrandomized one-group pre-test post-test design. Pemilihan desain penelitian didasari oleh pertimbangan bahwa tidak memungkinkan dilakukan randomisasi untuk membagi partisipan ke dalam kelompok eksperimen dan kelompok kontrol (Yuwanto, 2012).

Penelitian ini tidak menggunakan kelompok kontrol karena keterbatasan jumlah peserta yang dapat mengikuti program psikoedukasi. Peneliti melakukan pre-test dan post-test untuk mengetahui perbedaan pengetahuan dan sikap peserta sebelum dan sesudah program psikoedukasi diberikan. Berikut ini merupakan bagan desain penelitian ini.

\begin{tabular}{|llllll|}
\hline NR & O1 & -------- & $X$ & -------- & O2 \\
\hline
\end{tabular}

Gambar 1. Desain Penelitian

Keterangan:
NR : Non Random
O1 : Pretest Pengetahuan dan Sikap
$\mathrm{X}$ : Psikoedukasi C4ME
O2 : Posttest Pengetahuan dan

\section{Partisipan}

Partisipan dalam penelitian ini adalah 15 orang taruni yang berasal dari dua angkatan taruni militer, yang sedang menjalani pendidikan di tahun kedua dan ketiganya. Mereka tinggal bersama dalam asrama taruni. Beberapa taruni tidak dapat mengikuti program psikoedukasi karena mengikuti pelayaran Jalayudha. Kriteria inklusi partsipan penelitian ini adalah 1) Berusia remaja akhir hingga dewasa awal yaitu berusia 19-21 tahun; 2) Berstatus sebagai taruni aktif di AAL; 3) Mengalami gangguan pramenstruasi selama minimal satu bulan terakhir serta bersedia mengikuti seluruh pelaksanaan program psikoedukasi dari awal hingga akhir acara; 4) Bersedia mengisi informed consent sebagai bukti tertulis kesediaan terlibat da- lam penelitian.

\section{Pengumpulan Data}

Pemetaan masalah kesehatan yang dihadapi komunitas taruni AAL merupakan proses analisis kebutuhan program intervensi untuk para taruni. Pengumpulan data pada tahap ini dilakukan dengan melakukan survei melalui wawancara pada taruni, komandan dan dokter klinik AAL serta observasi.

Pada tahap pelaksanaan intervensi psikoeduasi, peneliti mengumpulkan data melalui pengisian skala dan observasi untuk setiap partisipan. Skala yang digunakan adalah skala sikap terhadap menstruasi dan kuesioner yang mengukur tingkat pengetahuan taruni tentang kesehatan reproduksi, perilaku sehat saat menstruasi serta belief terhadap menstruasi. Kuesioner untuk mengukur pengetahuan taruni berbentuk lembar kerja yang terdiri dari 15 pertanyaan pilihan ganda dan 5 pertanyaan isian singkat (tabel 1).

Tabel 1. Blueprint kuesioner pengetahuan kesehatan reproduksi

\begin{tabular}{lccccc}
\hline \multirow{2}{*}{ Aspek } & \multicolumn{2}{c}{ Nomor Item } & & \\
\cline { 2 - 3 } & $\begin{array}{c}\text { Pilihan } \\
\text { ganda }\end{array}$ & $\begin{array}{c}\text { Isian } \\
\text { singkat }\end{array}$ & $\Sigma$ & $\%$ \\
\hline $\begin{array}{l}\text { Pengetahuan organ } \\
\text { reproduksi dan } \\
\text { proses menstruasi }\end{array}$ & $\begin{array}{c}1,2,3,4, \\
7,13\end{array}$ & 1 & 7 & 35 \\
$\begin{array}{l}\text { Perilaku sehat saat } \\
\text { menstruasi }\end{array}$ & $\begin{array}{c}6,11,12, \\
14,15\end{array}$ & 2,3 & 7 & 35 \\
$\begin{array}{l}\text { Belief tentang } \\
\text { menstruasi }\end{array}$ & $5,8,9$, & 4,5 & 6 & 30 \\
\hline \multicolumn{1}{c}{ Total Item } & & 20 item \\
\hline
\end{tabular}

Sedangkan skala sikap yang digunakan mengukur sikap terhadap menstruasi berbentuk skala Likert berjumlah 60 item. Skala sikap diujicobakan pada 25 orang taruni AAL. Dari 65 item yang diujicobakan, ada 5 item yang gugur. Adapun batas kriteria validitas item adalah 0,3 dengan koefisien reliabilitas 0,91. 
Follow-up dari intervensi dilakukan dengan menggunakan check list perilaku yang menggambarkan perilaku sehat saat sedang menstruasi dan frekuensi permohonan absen atau dispensasi untuk tidak mengikuti latihan fisik rutin. Pengambilan data pada proses follow-up dilakukan dengan metode wawancara dan observasi.

\section{Prosedur Intervensi}

Intervensi psikoedukasi C4ME ini dilakukan dalam satu hari dan terdiri dari empat sesi. Metode yang digunakan dalam psikoedukasi adalah ceramah, diskusi kelompok, menonton video dan games. Intervensi dilakukan dengan pendekatan berbasis kognitif perilaku dengan modifikasi teknik CBT yang bersifat praktikal yaitu restrukturisasi kognitif (positive reframing), positive self talk, imagery dan relaksasi pernafasan dengan gerakan yoga.

Asesmen dilakukan dengan pendekatan komunitas yaitu dengan mengacu pada teori ekologi Bronfenbenner (Eriksson, Ghazinour, \& Hammarström, 2018). Berkaitan dengan mikrosistem, peneliti melakukan wawancara pada taruni AAL. Hal ini dilakukan untuk mengetahui masalah dari sudut pandang taruni. Terkait dengan mesosistem, wawancara dilakukan pada dokter klinik AAL dan komandan taruni untuk menggali belief tentang kesehatan reproduksi, dukungan lingkungan terhadap masalah gangguan menstruasi taruni serta penanganan yang telah dilakukan. Terkait makrosistem, peneliti melakukan wawancara dengan pimpinan AAL mengenai peraturan atau kebijakan terkait dengan kesehatan reproduksi taruni serta ketersediaan sarana dan prasarana yang mendukung kesehatan reproduksi taruni.

Setelah proses asesmen selesai, peneliti merangkum data wawancara dan menarik keterkaitan antara data yang tergali dari mikrosistem, mesosistem dan makrosistem untuk dianalisis dengan model Health Belief Model (HBM). Model ini menjelaskan bahwa keputusan individu untuk melakukan perilaku sehat didasarkan pada dua jenis penilaian (aprraisal) yaitu belief terhadap ancaman penyakit (perceived susceptibilty, perceived severity) dan belief terhadap perilaku sehat tersebut.

Dari analisis berbagai faktor tersebut di atas, kecenderungan perilaku yang muncul adalah tidak memedulikan kebersihan diri saat menstruasi dengan tidak mengganti pembalut sepanjang hari dan menghindar dari latihan fisik dengan alasan sakit. Peneliti juga menganalisis faktor resiko dan faktor protektif yang berkaitan dengan karakteristik peserta dan lingkungan hidupnya. Oleh karena itu dari hasil analisis tersebut maka peneliti merancang sesi psikoedukasi sebagai berikut :

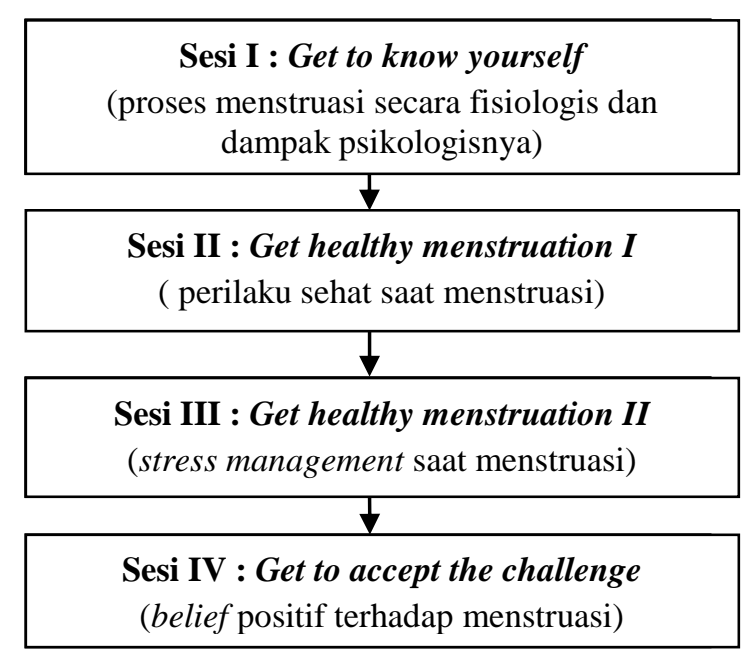

Gambar 2. Urutan Sesi Psikoedukasi

Aktivitas psikoedukasi C4ME ini meliputi: 1) penyampaian materi tentang topik terkait pada tiap sesi; 2) diskusi bersama terkait masalah PMS dan kesulitan psikologis yang dialami saat menstruasi; 3) membangun pemahaman yang positif dan benefit dari sisi kesehatan terhadap perilaku sehat saat menstruasi; 4) proses refleksi kelompok terkait belief negatif lawan positif terhadap menstruasi serta dampaknya pada kesehatan fisik dan psikologis taruni; dan 5) hands on learning melalui praktek langsung skill yang diajarkan.

Pada sesi pertama, peserta diajak untuk memahami keunikan dari kodratnya secara fisik dan psikologis serta diajak 
menerima dampak positif dan negatifnya. Teknik yang dipakai adalah teknik positive reframing.

Pada sesi kedua dan ketiga, peserta diajarkan cara praktis untuk melakukan perilaku sehat untuk merawat kesehatan fisik dan psikologis saat menstruasi. Pendekatan kognitif perilaku yang digunakan adalah mindfulness. Partisipan diajarkan gerakan yoga sederhana yang dapat mengurangi intensitas gejala PMS seperti memerbaiki mood, mengurangi sakit kepala dan kram perut. Strategi stress management yang praktis juga dilakukan dengan metode relaksasi, self-talk dan imagery. Pada sesi keempat partisipan diajak untuk melakukan refleksi terhadap belief-belief negatif yang terbangun karena situasi hidupnya yang telah berubah sebagai taruni militer dan mendiskusikan dampak belief tersebut pada kesehatan fisik maupun psikologisnya.

\section{Analisis Data}

Analisis data dilakukan secara kuantitatif yaitu melalui uji normalitas dan uji hipotesis. Uji normalitas menggunakan Shapiro-Wilk test karena lebih akurat untuk subjek berjumlah kurang dari 50 . Hasilnya menunjukkan semua jenis data berdistribusi normal (nilai Sig.>0.05), kecuali hasil post-test variabel sikap terhadap mentruasi. Berdasarkan uji normalitas tersebut, uji hipotesis dilakukan secara parametrik menggunakan uji compare means metode paired sample test (T-Correlated Sample) pada data evaluasi pengetahuan, sedangkan pada data skala sikap dilakukan uji non-parametrik Wilcoxon. Analisis data kuantitatif dilakukan dengan menggunakan bantuan SPSS ver.16.00 for windows.

\section{Hasil}

Hasil analisis data deskriptif seperti terlihat pada tabel 2 dan tabel 3 menunjukkan terjadi peningkatan pengetahuan maupun sikap positif terhadap menstruasi pada para partisipan. Namun, seperti tam-
Tabel 2. Distribusi Frekuensi Berdasarkan Skor Pengetahuan

\begin{tabular}{clcccc}
\hline No & Nama & $\begin{array}{c}\text { Skor } \\
\text { Pretest }\end{array}$ & $\begin{array}{c}\text { Skor } \\
\text { Posttest }\end{array}$ & $\begin{array}{c}\text { Gain } \\
\text { score }\end{array}$ & Ket. \\
\hline 1 & DA & 60 & 75 & 15 & Naik \\
2 & SAZ & 60 & 85 & 25 & Naik \\
3 & SDA & 60 & 70 & 30 & Naik \\
4 & AS & 60 & 100 & 40 & Naik \\
5 & RAW & 75 & 90 & 15 & Naik \\
6 & MIP & 75 & 80 & 5 & Naik \\
7 & DCR & 80 & 90 & 10 & Naik \\
8 & IHR & 60 & 85 & 25 & Naik \\
9 & AD & 60 & 80 & 20 & Naik \\
10 & MAF & 75 & 90 & 15 & Naik \\
11 & BNR & 50 & 70 & 20 & Naik \\
12 & EJ & 50 & 70 & 20 & Naik \\
13 & BCT & 60 & 90 & 30 & Naik \\
14 & KA & 55 & 70 & 15 & Naik \\
15 & DNL & 60 & 75 & 15 & Naik \\
\hline
\end{tabular}

Tabel 3. Distribusi Frekuensi Berdasarkan Sikap Terhadap Menstruasi

\begin{tabular}{clcccc}
\hline No & Nama & $\begin{array}{c}\text { Skor } \\
\text { Pretest }\end{array}$ & $\begin{array}{c}\text { Skor } \\
\text { Posttest }\end{array}$ & $\begin{array}{c}\text { Gain } \\
\text { score }\end{array}$ & Ket. \\
\hline 1 & DA & 168 & 204 & 36 & Naik \\
2 & SAZ & 168 & 210 & 42 & Naik \\
3 & SDA & 162 & 206 & 44 & Naik \\
4 & AS & 163 & 210 & 47 & Naik \\
5 & RAW & 181 & 207 & 26 & Naik \\
6 & MIP & 165 & 167 & 2 & Tetap \\
7 & DCR & 166 & 172 & 6 & Tetap \\
8 & IHR & 157 & 170 & 13 & Naik \\
9 & AD & 184 & 208 & 24 & Naik \\
10 & MAF & 169 & 207 & 38 & Naik \\
11 & BNR & 164 & 189 & 25 & Naik \\
12 & EJ & 175 & 205 & 30 & Naik \\
13 & BCT & 170 & 206 & 36 & Naik \\
14 & KA & 167 & 203 & 36 & Naik \\
15 & DNL & 165 & 207 & 42 & Naik \\
\hline
\end{tabular}

pak di tabel 3, terdapat dua peserta yang tidak mengalami kenaikan skor sikap yang signifikan. Proses belajar kedua partisipan tersebut memang kurang optimal karena harus meninggalkan kegiatan psikoeduasi selama 1,5 jam karena mengikuti kegiatan dan briefing bersama komandannya.

Hasil uji beda menunjukkan perbeda- 
an signifikan antara sebelum dan setelah intervensi pada pengetahuan partisipan tentang menstruasi. Seperti tercantum pada tabel 4, rata-rata skor pengetahuan setelah intervensi (posttest) $(\mathrm{M}=81.33)$ lebih tinggi daripada sebelum intervensi $(\mathrm{M}=62.67)$. Selain itu hasil uji hipotesis paired simple t-test menunjukkan bahwa Asymp sig. (2tailed) adalah $0.001(\mathrm{p}<0.05)$ dengan perbedaan rerata sebesar -18.66. Hal ini mengindikasikan bahwa terdapat perbedaan yang signifikan pada pengetahuan partisipan antara sebelum dan sesudah mengikuti psikoedukasi. Jadi, psikoedukasi C4ME efektif dalam meningkatkan pengetahuan partisipan tentang gangguan paramenstruasi.

Tabel 4. Hasil Uji Beda Pengetahuan Sebelum dan Sesudah Intervensi

\begin{tabular}{|c|c|c|c|c|}
\hline \multicolumn{2}{|c|}{ Mean } & \multicolumn{2}{|c|}{ SD } & \multirow{2}{*}{$\begin{array}{c}\text { Sign. } \\
\text { (2-tailed) }\end{array}$} \\
\hline Pretest & Posttest & Pretest & Posttest & \\
\hline 62,67 & 81.33 & 9.23 & 9.54 & 0,00 \\
\hline
\end{tabular}

Tabel 5. Hasil Uji Beda Sikap Sebelum dan Sesudah Intervensi

\begin{tabular}{ccccc}
\hline \multicolumn{2}{c}{ Mean } & \multicolumn{2}{c}{ SD } & Sign. \\
Pretest & Posttest & Pretest & Posttest & (2-tailed) \\
\hline 168.27 & 198.72 & 7.07 & 15.51 & 0,001 \\
\hline
\end{tabular}

Berdasarkan tabel 5, dapat dijelaskan bahwa rata-rata skor sikap partisipan setelah mengikuti intervensi $(M=168.27)$ lebih besar daripada sebelum mengikuti intervensi $(\mathrm{M}=198.72)$. Hasil uji hipotesis dengan uji Wilcoxon menunjukkan bahwa Asymp sig. (2-tailed) yaitu $0.001(\mathrm{p}<0.05)$ dengan perbedaan rerata sebesar -30.45 . Hal ini menunjukkan bahwa terdapat perbedaan signifikan pada skor sikap partisipan terhadap menstruasi sebelum dan sesudah diberikan psikoedukasi. Tidak ada partisipan yang mengalami penurunan skor sikap dan hanya dua orang saja skor sikapnya tetap (tidak mengalami kenaikan). Karena itu, dapat disimpulkan bahwa intervensi psikoedukasi C4ME berhasil mengubah sikap partisipan menjadi lebih positif terhadap menstruasi.

Penghitungan effect size dilakukan dengan tujuan untuk mengukur seberapa besar jarak antara dua skor yang ditunjukkan oleh mean skor tersebut. Berdasarkan Cohen's (d), nilai effect size berkisar antara 0 hingga 1 , dengan nilai $d$ $0.20 ; 0.50$ dan 0.80 mewakili efek kecil, sedang dan besar. Namun Sawilowsky (2009) menambahkan kategori effect size Cohen $(d)$ menjadi enam kategori dengan memperluas kisaran nilai d yaitu dari $d=0.01$ sampai $d=2.0$ sehingga terdapat enam kategori effect size seperti tampak pada tabel 6.

Tabel 6. Perkembangan Kategorisasi Nilai Cohen Menurut Sawilowsky

\begin{tabular}{lcc}
\hline \multicolumn{1}{c}{ Effect Size } & Nilai d & Referensi \\
\hline $\begin{array}{l}\text { Sangat kecil (very } \\
\text { small) }\end{array}$ & .01 & Sawilowsky, 2009 \\
$\begin{array}{l}\text { Kecil (small) } \\
\text { Sedang (medium) }\end{array}$ & .50 & Cohen, 1988 \\
$\begin{array}{l}\text { Besar (large) } \\
\begin{array}{l}\text { Sangat besar } \\
\text { (very large) }\end{array}\end{array}$ & .80 & Cohen, 1988 \\
$\begin{array}{l}\text { Amat sangat besar } \\
\text { (huge) }\end{array}$ & 2.00 & Sawilowsky, 2009 \\
\hline
\end{tabular}

Hasil perhitungan effect size untuk skor sikap terhadap menstruasi bernilai 1.369. Hal ini mengindikasikan bahwa terdapat perbedaan yang sangat besar antara skor pretest dan posttest sikap partisipan terhadap menstruasi. Dapat disimpulkan bahwa psikoedukasi memiliki efek yang sangat besar terhadap kenaikan skor skala sikap, artinya intervensi psikoedukasi tersebut tergolong efektif untuk mengubah sikap partisipan menjadi lebih positif terhadap menstruasi.

Hasil análisis data kualitatif juga menunjukkan bahwa lebih dari 50\% dari partisipan kurang mampu mendeskripsikan keuntungan mengalami menstruasi. Data 
seperti tercantum pada Tabel 7 mendeskripsikan hasil koding lembar kerja partisipan terkait hal tersebut. Setelah mengikuti psikoedukasi, sebagian besar partisipan $(86,67 \%)$ dapat menyebutkan sisi positif mengalami menstruasi terutama dari perspektif fungsi reproduksi yang sehat.

Tabel 7. Tabulasi Data Kualitatif Benefit Mengalami Menstruasi

\begin{tabular}{lcccc}
\hline & \multicolumn{2}{c}{$\begin{array}{c}\text { Sebelum } \\
\text { psikoedukasi }\end{array}$} & \multicolumn{2}{c}{$\begin{array}{c}\text { Setelah } \\
\text { psikoedukasi }\end{array}$} \\
\cline { 2 - 5 } & $\Sigma$ & $\%$ & $\Sigma$ & $\%$ \\
\hline $\begin{array}{l}\text { Bukti bahwa aku } \\
\text { adalah perempuan } \\
\text { sehat }\end{array}$ & 3 & 20 & 8 & 53,33 \\
$\begin{array}{l}\text { Kesehatan } \\
\text { reproduksiku } \\
\text { normal/baik }\end{array}$ & 1 & 6,67 & 5 & 33,34 \\
$\begin{array}{l}\text { Aku baik-baik saja } \\
\begin{array}{l}\text { Tidak ada } \\
\text { keuntungannya }\end{array}\end{array}$ & 3 & 20 & 2 & 13,33 \\
\hline \begin{tabular}{l} 
Total \\
\hline
\end{tabular} & 15 & 100 & 15 & 100 \\
\hline
\end{tabular}

Data juga menunjukkan terjadinya perubahan belief terhadap menstruasi antara sebelum dan sesudah intervensi (Tabel 8). Sebelum psikoedukasi, mayoritas partisipan $(66,67 \%)$ menganggap bahwa menstruasi adalah beban, memalukan serta mencerminkan kelemahan perempuan. Setelah mengikuti psikoedukasi, lebih dari $85 \%$ partisipan manyatakan dapat menerima menstruasi sebagai kodrat atau takdir perempuan dan menganggapnya sebagai indikator fungsi reproduktif yang sehat.

\section{Pembahasan}

Hasil intervensi dalam bentuk psikoedukasi C4ME ini terbukti dapat menjawab hipotesis penelitian yaitu dapat mengubah sikap partisipan menjadi lebih positif terhadap menstruasi. Hal ini juga didukung penelitian sebelumnya yang melaporkan bahwa intervensi psikososial seperti psikoedukasi merupakan metode
Tabel 8. Makna Tabulasi Data Kualitatif Menstruasi

\begin{tabular}{|c|c|c|c|c|}
\hline \multirow{2}{*}{ Deskripsi Jawaban } & \multicolumn{2}{|c|}{$\begin{array}{c}\text { Sebelum } \\
\text { psikoedukasi }\end{array}$} & \multicolumn{2}{|c|}{$\begin{array}{c}\text { Setelah } \\
\text { psikoedukasi }\end{array}$} \\
\hline & Jumlah & $\%$ & Jumlah & $\%$ \\
\hline $\begin{array}{l}\text { Beban / sesuatu } \\
\text { yang merepotkan, } \\
\text { memalukan, simbol } \\
\text { kelemahan }\end{array}$ & 10 & 66,67 & 2 & 13,33 \\
\hline $\begin{array}{l}\text { Kodrat dan takdir } \\
\text { perempuan; } \\
\text { indikator fungsi } \\
\text { reproduktif yang } \\
\text { sehat }\end{array}$ & 2 & 13,34 & 13 & 86,67 \\
\hline $\begin{array}{l}\text { Hal yang } \\
\text { menyakitkan }\end{array}$ & 3 & 20 & 0 & 0 \\
\hline
\end{tabular}

yang efektif untuk meningkatkan pengetahuan tentang gangguan pramenstruasi sekaligus mengubah sikap menjadi lebih positif terhadap menstruasi (Chau \& Chang, 1999; Darestani, Komeili, \& Jalili, 2017; Taghizadeh, Shirmohammadi, Feizi, \& Arbabi, 2013).

Pada penelitian ini, data kualitatif dapat menjelaskan hasil data kuantitatif. Data dalam tabel 7 dan 8 mengindikasikan bahwa setelah intervensi, terjadi perubahan atribusi pada proses berpikir taruni yang terkait dengan benefit menstruasi dan pemaknaan gangguan pramenstruasi. Hal ini yang menjadi kunci perubahan sikap taruni pada menstruasi. Data tersebut didapatkan melalui sesi diskusi dalam kelompok. Pada sesi tersebut, anggota kelompok dapat berdiskusi dan berbagi pikiran maupun perasaan mereka secara terbuka sehingga dapat merasakan dukungan temanteman dari berbagai angkatan yang juga mengalami masalah serupa (Brabender, Fallon \& Smolar, 2004). Hasil intervensi kelompok ini selaras dengan penelitian sebelumnya yang menunjukkan bahwa bentuk intervensi kelompok lebih berdampak positif bagi kesejahteraan psikologis para siswi yang tinggal dalam asrama dan rentan mengalami konflik personal (Maddineshat, Keyvanloo, Lashkardoost, Arki, \& Tabatabaeichehr, 2016).

Dukungan emosional yang dirasakan 
oleh partisipan melalui sesi diskusi juga ditengarai menjadi penyebab perubahan sikap partisipan terhadap menstruasi. Hal ini didukung oleh Ussher dan Perz (2013) yang menyatakan bahwa dukungan emosional dari teman dapat menurunkan simtom gangguan pramenstruasi. Dukungan emosional yang adekuat dapat berpengaruh positif pada kesehatan fisik maupun emosional individu. Dukungan emosional ini terutama dalam bentuk relasi yang penuh empati yang diekspresikan secara verbal (Jiang, Drolet, \& Kim, 2018; Kang, Park, \& Wallace, 2016; Rezaee, Mahamed, \& Amidi Mazaheri, 2015). Dukungan emosional yang penuh empati tampak pada perilaku mendengarkan dengan penuh perhatian serta memberi kenyamanan melalui ucapan yang menenangkan (Heidari,2009). Dukungan ini dapat meningkatkan rasa percaya diri dan menurunkan simtom emosional gangguan pramenstruasi.

Kurangnya dukungan emosional yang dirasakan taruni terkait gangguan pramenstruasi merupakan salah satu kondisi yang harus dihadapi personil militer di lingkungan tugasnya. Hal ini disebabkan oleh penekanan prinsip maskulinitas dalam dunia militer telah menjadi penghambat kebebasan ekspresi emosional yang adaptif terutama saat mengelola emosi negatif (McAllister, Callaghan, \& Fellin, 2019). Hal ini dapat berdampak negatif pada kesehatan mental para personil militer termasuk taruni. Harms, Krasikova, Vanhove, Herian dan Lester (2013) juga mengemukakan bahwa kondisi ini merupakan faktor resiko yang harus diahadapi oleh semua personil militer.

Selain adanya dukungan emosional dari peer-group, perubahan atribusi partisipan juga dipengaruhi oleh teknik kognitif yang dipakai dalam intervensi (Hosey, McWhorter, \& Wegener, 2018; Marasigan, 2019). Teknik restrukturisasi kognitif yang mengubah distorsi berpikir menjadi lebih logis dan adaptif juga berperan untuk mengubah belief dan atribusi yang negatif menjadi lebih positif. Pikiran yang lebih positif akan memicu optimisme dan memudahkan partisipan untuk mengatasi simtom gangguan pramenstruasinya (Read et al., 2014), misalnya dengan cara memperbanyak konsumsi makanan bergizi, melakukan relaksasi dan memberi dukungan verbal pada teman. Perubahan pada atribusi berkontribusi pada perubahan sikap yang lebih positif.

Pendekatan mindfulness yang diterapkan dalam proses intervensi juga membantu untuk menanamkan kesadaran yang bersifat present awareness dan nonjudgemental. Hal ini berpengaruh dalam mendukung perubahan sikap serta menurunkan simtom pramenstruasi yang dialami partisipan (Bluth, Gaylord, Nguyen, Bunevicius, \& Girdler, 2015; Lustyk et al., 2011).

Keterbatasan penelitian ini adalah tidak adanya kelompok kontrol sebagai pembanding sehingga peneliti tidak bisa mengetahui dengan pasti peningkatan skor pengetahuan dan sikap taruni terhadap menstruasi disebabkan oleh adanya intervensi atau faktor lain di luar intervensi. Keterbatasan lainnya adalah waktu psikoedukasi yang kurang panjang sehingga peneliti tidak bisa mengevaluasi kemampuan partisipan melakukan keterampilan yang dilatihkan dalam psikoedukasi.

\section{Simpulan}

Program psikodukasi C4ME bagi para taruni AAL ini terbukti efektif dalam meningkatkan pengetahuan terkait kesehatan menstruasi. Diperlukan intervensi psikologis untuk mengubah sikap taruni AAL menjadi lebih positif terhadap menstruasi. Dalam hal ini, intervensi yang terbukti efektif adalah psikoedukasi dengan pendekatan kognitif-perilaku melalui teknik mindfuless dan CBT. Selain itu, disimpulkan bahwa dukungan emosional menjadi faktor protektif yang penting untuk ditingkatkan dalam menangani gangguan pramenstruasi yang dialami oleh taruni AAL. 


\section{Saran}

Saran pada pihak Akademi Angkatan Laut adalah agar mengadakan psikoedukasi secara rutin tentang kesehatan reproduksi khususnya tentang menstruasi pada taruni tahun pertama. Hal ini mengingat perbedaan situasi pendidikan milier yang rentan menjadi stressor bagi taruni. Hal ini berpotensi untuk memicu gangguan pramenstruasi pada taruni AAL. Psikoedukasi yang diadakan secara rutin juga dapat menjadi kesempatan yang baik bagi para taruni untuk menjalin relasi yang penuh empati dengan teman-temannya. Hal ini dapat meningkatkan faktor protektif dukungan emosional yang dapat menurunkan simtom gangguan pramenstruasi.

Penelitian selanjutnya disarankan untuk mengkaji lebih jauh tentang peran dukungan emosional terhadap kesejahteraan psikologis taruni yang mengalami gangguan pramenstruasi.

\section{Daftar Pustaka}

Askari, S., Behroozi, N., \& Abbaspoor, Z. (2018). The effect of mindfulnessbased cognitive-behavioral therapy on premenstrual syndrome. Iranian Red Crescent Medical Journal, 20(2). e57538. https://doi.org/10.5812/ircmj.57538

Brabender, V. A., Fallon, A. E., \& Smolar, A. I. (2004). Essential of group therapy. New Jersey : John Wiley \& Sons,Inc.

Bashiri, Z., Aghajani, M., \& Alavi, N. M. (2016). Effects of psychoeducation on mental health in patients with coronary heart disease. Iranian Red Crescent Medical Journal, 18(5). e25089. https://doi.org/10.5812/ircmj.25089

Blake, F. (1995). Cognitive therapy for Premenstrual Syndrome. Cognitive and Behavioral Practice, 2(1), 167185. https://doi.org/10.1016/S10777229(05)80009-4

Bluth, K., Gaylord, S., Nguyen, K., Bunevicius, A., \& Girdler, S. (2015). Mindfulness-Based Stress Reduction as a Promising Intervention for Amelioration of Premenstrual Dysphoric Disorder Symptoms. Mindfulness. 6(6): 1292-1302. https://doi.org/10.1007/s12671-0150397-4
Budarapu, S., Sadam, H., Harshitha, K., Nageswari M D., Reddy K, H., \& Dhanekula, G. (2018). Section: Psychiatry A Study to Assess the Prevalence of Premenstrual Syndrome and Premenstrual Dysphoric Disorder and Various Coping Strategies used by Students in A Womens Medical College from South India. International Journal of Contemporary Medical Research 5(11), K1-K5. http://dx.doi.org/10.21276/ijcmr.201 8.5.11.18

Chau, J. P. C., \& Chang, A. M. (1999). Effects of an educational programme on adolescents with premenstrual syndrome. Health Education Research, 14(6), 817-830. https://doi.org/10.1093/HER/14.6.81 7

Chrisler, J. C. (2008). 2007 Presidential address: Fear of losing control: Power, perfectionism, and the psychology of women. Psychology of Women Quarterly, 32(1),1-12. https://doi.org/10.1111/j.14716402.2007.00402.x

Chrisler, J. C., Gorman, J. A., \& Streckfuss, L. (2014). Self-Silencing, Perfectionism, Dualistic Discourse, Loss of Control, and the Experience 
of Premenstrual Syndrome. Women's Reproductive Health, 1(2), 138-152.

https://doi.org/10.1080/23293691.20 14.966597

Do, J. J., Samuels, S. M., Adkins, D. J., Clinard, M. E., \& Koveleskie, A. J. (2013). Gender bias and pluralistic ignorance in perceptions of fitness assessments. Military Psychology, 25(1), 23-35. https://doi.org/10.1037/h0094754

Eriksson, M., Ghazinour, M., \& Hammarström, A. (2018). Different uses of Bronfenbrenner's ecological theory in public mental health research: what is their value for guiding public mental health policy and practice? Social Theory and Health, 16(4), 414-433. https://doi.org/10.1057/s41285-0180065-6

Estiani, K., \& Nindya, T. S. (2018). Hubungan Status Gizi Dan Asupan Magnesium Dengan Kejadian Premenstrual Syndrome (Pms) Pada Remaja Putri. Media Gizi Indonesia, 13(1), 20. https://doi.org/10.20473/mgi.v13i1.2 $0-26$

Forrester-Knauss, C., Zemp Stutz, E., Weiss, C., \& Tschudin, S. (2011). The interrelation between premenstrual syndrome and major depression: Results from a population-based sample. $B M C$ Public Health, 11.795. https://doi.org/10.1186/1471-245811-795

Ghafoori, B., Fisher, D., Korosteleva, O., \& Hong, M. (2016). A Randomized, Controlled Pilot Study of a SingleSession Psychoeducation Treatment for Urban, Culturally Diverse, Trauma-Exposed Adults. Journal of Nervous and Mental Disease, 204(6), 421-430. https://doi.org/10.1097/NMD.00000

\section{2}

Harms, P. D., Krasikova, D. V., Vanhove, A. J., Herian, M. N., \& Lester, P. B. (2013). Stress and emotional wellbeing in military organizations. Research in Occupational Stress and Well Being, 11, 103-132. https://doi.org/10.1108/S14793555(2013)0000011008

Hosey, M., McWhorter, J. W., \& Wegener, S. T. (2018). Psychologic Interventions for Chronic Pain. In Essentials of Pain Medicine (pp. 539-544.e1)

https://doi.org/10.1016/b978-0-32340196-8.00059-0

Hourani, L. L., Yuan, H., \& Bray, R. M. (2004). Psychosocial and lifestyle correlates of premenstrual symptoms among military women. Journal of Women's Health. 13(7), 812-821. https://doi.org/10.1089/jwh.2004.13. 812

Ilagan, G., Ilagan, J., Simpson, A. N., Shealy, T., Bennett-Mintz, J., \& McCormick, K. (2016). Outcomes from an Undergraduate Cadet Women's Backpacking Experience. Research in Outdoor Education, 14(1), 21-40. https://doi.org/10.1353/roe.2016.000 1

Jiang, L., Drolet, A., \& Kim, H. S. (2018). Age and Social Support Seeking: Understanding the Role of Perceived Social Costs to Others. Personality and Social Psychology Bulletin, 44(7), 1104-1116. https://doi.org/10.1177/0146167218 760798

Kang, H. W., Park, M., \& Wallace (Hernandez), J. P. (2016). The impact of perceived social support, loneliness, and physical activity on quality of life in South Korean older adults. Journal of Sport and Health Science, $\quad 7(2), \quad 237-244$. 
https://doi.org/10.1016/j.jshs.2016.0 5.003

Karimi, Z., Dehkordi, M. A., Alipour, A., \& Mohtashami, T. (2018). Treatment of premenstrual syndrome: Appraising the effectiveness of cognitive behavioral therapy in addition to calcium supplement plus vitamin D. PsyCh Journal, 7(1), 4150. https://doi.org/10.1002/pchj.206

Darestani, M. K., Komeili, A., \& Jalili, Z. (2017). The Effect of Educational Intervention Based on The Health Belief Model on Improvement of Preventive Behaviors Towards Premenstrual Syndrome (PMS) Among Girls of Pre-University in Tehran. Nian Journal of Health Education and Health Promotion, 05(03), 251-259. https://doi.org/10.30699/acadpub.ijh ehp.5.3.251

King, M., \& Ussher, J. M. (2013). It's not all bad: Women's construction and lived experience of positive premenstrual change. Feminism and Psychology, 23(3), 399-417. https://doi.org/10.1177/0959353512 440351

Kleinstäuber, M., Schmelzer, K., Ditzen, B., Andersson, G., Hiller, W., \& Weise, C. (2016). Psychosocial Profile of Women with Premenstrual Syndrome and Healthy Controls: A Comparative Study. International Journal of Behavioral Medicine, 23(6). 752-763. https://doi.org/10.1007/s12529-0169564-9

Lustyk, M. K. B., Gerrish, W. G., Douglas, H., Bowen, S., \& Marlatt, G. A. (2011). Relationships Among Premenstrual Symptom Reports, Menstrual Attitudes, and Mindfulness. Mindfulness, 2(1), 3748. https://doi.org/10.1007/s12671011-0041-x
Lustyk, M. K. B., Gerrish, W. G., Shaver, S., \& Keys, S. L. (2009). Cognitivebehavioral therapy for premenstrual syndrome and premenstrual dysphoric disorder: A systematic review. Archives of Women's Mental Health, 12(2), 85-96. https://doi.org/10.1007/s00737-0090052-y

Maddineshat, M., Keyvanloo, S., Lashkardoost, H., Arki, M., \& Tabatabaeichehr, M. (2016). Effectiveness of group cognitivebehavioral therapy on symptoms of premenstrual syndrome (PMS). Iranian Journal of Psychiatry, 11(1), 30-36.

https://www.ncbi.nlm.nih.gov/pmc/a rticles/PMC4888138/pdf/IJPS-1130.pdf

McAllister, L., Callaghan, J. E. M., \& Fellin, L. C. (2019). Masculinities and emotional expression in UK servicemen: 'Big boys don't cry'? Journal of Gender Studies, 28(3), 257-270.

https://doi.org/10.1080/09589236.20 18.1429898

Nakkas, C., Annen, H., \& Brand, S. (2016). Psychological distress and coping in military cadre candidates. Neuropsychiatric Disease and Treatment, 12, 2237-2243. https://doi.org/10.2147/NDT.S11322 0

Namsa,A.M., $\quad$ Palandeng,H., $\quad \&$ Kallo,V.D.(2015). Hubungan status gizi dengan sindrom premenstruasi pada remaja putri di SMA Frater Don Bosco Manado. e-Jurnal Keperawatan, 3(3), 1-7. https://ejournal.unsrat.ac.id/index.ph p/jkp/article/view/8780

Nashruna ,I.,Maryatum, \& Wulandari, R. (2012). Hubungan aktivitas olahraga dan obesitas dengan kejadian sindrom pramenstruasi di Desa Puncangmiliar Tulung Klaten. 
Jurnal Gaster. 9(1). 65-75. https://jurnal.aiska-

university.ac.id/index.php/gaster/arti cle/view/33

Perz, J., \& Ussher, J. M. (2006). Women's experience of premenstrual syndrome: A case of silencing the self. Journal of Reproductive and Infant Psychology, 24(4), 289-303. https://doi.org/10.1080/0264683060 0973883

Marasigan, P. R. (2019). Using brief cognitive restructuring and cognitive defusin technique to cope with negative thoughts. Social Values and Society, 1(4), 11-14. https://doi.org/10.26480/svs.04.2019 .11 .14

Rahmani, F., Ranjbar, F., Ebrahimi, H., \& Hosseinzadeh, M. (2015). The Effects of Group Psychoeducational Programme on Attitude toward Mental Illness in Families of Patients with Schizophrenia, 2014. Journal of Caring Sciences, 4(3), 243-251. https://doi.org/10.15171/jcs.2015.02 5

Ramadani, M. (2012). Premenstrual syndrome (PMS). Jurnal Kesehatan Masyarakat.,7(1),

21-25. http://jurnal.fkm.unand.ac.id/index.p $\mathrm{hp} / \mathrm{jkma} /$ article/view/103/109

Rapkin, A. J., \& Lewis, E. I. (2013, November). Treatment of premenstrual dysphoric disorder. Women's Health, 9(6), 537-56. https://doi.org/10.2217/whe.13.62

Read, J. R., Perz, J., \& Ussher, J. M. (2014). Ways of coping with premenstrual change: Development and validation of a premenstrual coping measure. BMC Women's Health, 14(1), 1-15. https://doi.org/10.1186/1472-687414-1

Reberte, L. M., de Andrade, J. H. C., Hoga, L. A. K., Rudge, T., \&
Rodolpho, J. R. C. (2014). Men's Perceptions and Attitudes Toward the Partner With Premenstrual Syndrome. American Journal of Men's Health, 8(2), 137147.https://doi.org/10.1177/1557988 313497050

Rezaee, H., Mahamed, F., \& Amidi Mazaheri, M. (2015). Does Spousal Support Can Decrease Women's Premenstrual Syndrome Symptoms? Global Journal of Health Science, $8(5)$, 19-26. https://doi.org/10.5539/gjhs.v8n5p19

Sawilowsky, S. (2009). New Effect Size Rules of Thumb. Journal of Modern Applied Statistical Methods, 8(2). 597-599.

https://doi.org/10.22237/jmasm/1257 035100

Siahbazi, S., Montazeri, A., Taghizadeh, Z., \& Masoomie, R. (2018). The Consequences of Premenstrual Syndrome on the Quality of Life from the Perspective of Affected Women: A Qualitative Study. Journal of Research in Medical and Dental Science, 6(2), 284-292. https://doi.org/10.5455/jrmds.20186 243

Sigmon, S. T., Craner, J., Yoon, K. L., \& Thorpe, G. L. (2012). Premenstrual Syndrome (PMS). Encyclopedia of Human Behavior: Second Edition, 7(1), 167-173. https://doi.org/10.1016/B978-0-12375000-6.00288-3

Taghizadeh, Z., Shirmohammadi, M., Feizi, A., \& Arbabi, M. (2013). The effect of cognitive behavioural psycho-education on premenstrual syndrome and related symptoms. Journal of Psychiatric and Mental Health Nursing, 20(8),705-713 https://doi.org/10.1111/j.13652850.2012.01965.x

Ussher, J. M., \& Perz, J. (2010). Gender 
differences in self-silencing and psychological distress in informal cancer carers. Psychology of Women Quarterly, 34(2), 228-242. https://doi.org/10.1111/j.14716402.2010.01564.x

Ussher, J. M., \& Perz, J. (2013). PMS as a process of negotiation: Women's experience and management of premenstrual distress. Psychology and Health, 28(8), 909-27 https://doi.org/10.1080/08870446.20 13.765004

Yadav, R. N., Joshi, S., Poudel, R., \& Pandeya, P. (2018). Knowledge, Attitude, and Practice on Menstrual
Hygiene Management among School Adolescents. Journal of Nepal Health Research Council, 15(3), 212-216. https://doi.org/10.3126/jnhrc.v15i3.1 8842

Yuwanto, L. (2012). Pengantar metode penelitian. Jakarta: Dwi Putra Pustaka Jaya

Zendehdel, M., \& Elyasi, F. (2018). Biopsychosocial etiology of premenstrual syndrome: A narrative review. Journal of Family Medicine and Primary Care, 7(2), 346-356. https://doi.org/10.4103/jfmpc.jfmpc 336_17 